Journal of Social Sciences 7 (2): 232-240, 2011

ISSN 1549-3652

(C) 2010 Science Publications

\title{
A Study of Urban Quality of Life in a Developing Country
}

\author{
${ }^{1}$ Sedigheh Lotfi, ${ }^{2}$ Amin Faraji, ${ }^{2}$ Husain Hataminejad and ${ }^{2}$ Ahmad Pourahmad \\ ${ }^{1}$ Department of Geography and Urban Planning, University of Mazandaran, Iran \\ ${ }^{2}$ Department of Urban Planning, University of Tehran, Iran
}

\begin{abstract}
Problem statement: The rapid growth of urbanization has led to degradation of quality of life in many developing countries. The qualitative approach towards development concepts provided background for studying the object of quality of life. This concept was declared by Raymond Bauer in 1966 in response to the increase of urban crisis. Today, quality of life refers to the capacity of a place for living life. Approach: The present study aims to analyze quality of life by concentrating on the socio-economic, physical-environmental and mental indexes. The indexes were selected with respect to their importance by conducting a careful examination. The comparative analysis was applied based on hierarchical weighting. Observation and completing questionnaire have been two important tools in this research. Results: The results revealed that there are significant socio-economic gap among the different neighborhoods of the town. The mean of urban quality of life is 8.517 which show a moderate level of quality of life according to the research classification. Conclusion: The research came to conclusion that the different neighborhoods of the town showed different level of quality of life which it leads to socio-economic disparities among the urban zones. So the priority of planning should concentrate on the areas where deprivation decreased the level of quality of life.
\end{abstract}

Key words: Urban quality of life, social indexes, socio-economic gap, sustainable development

\section{INTRODUCTION}

The unprecedented growth of urbanization in developing countries has expanded the physical limits of cities and therefore undermined the qualitative development of such settlements. The resultant of the development has been emergence of disparities, extended poverty, environment pollution and malgrowth of urban places. The main concept of development derived initially from the modernization theory which was concentrated more on the positivistic approach but latter the new approach of development focused on the human aspects by giving priority to the social and cultural dimensions (Morris, 1998; Naghdi and Sadeghi, 2006). This new approach inserted a new concept into the literature of development as quality of life. Quality of life refers 'to the more or less 'good' or 'satisfactory' character of people's life: The concept has several interesting attributes: (1) it refers to human life only, (2) it is rarely if everused in the plural, (3) it is used as a single indivisible generic term whose meaning can be clarified and (4) it is difficult to classify into any discrete category of related social sciences. Despite the absence of a single definition, there are many similarities and correlations among the concepts which are applied by scientists for measuring this concept. The concept Quality of Life was considered by Raymond Baer in his book "social indexes" in 1966 (Mahdizadeh, 2003) and then it gained attention by different scholars in the aftermath of "urban crisis". Gradually most of the developed world attempted to promote the level of their people in urban areas in 1980s. Today the indicator of quality of life is widely tied with the concept of sustainable development and is an important part of it (Fahy, 2007). For example Britain exploited the concept of quality of life as criteria to targeting sustainable development in 1999. It considered sustainable development as simple thought but comprehensive and sufficient for guaranteeing the quality of life for present and future generations which could bring socio-economic and environmental welfare.

The statement of quality of life is complicated concept which many social scientists (Table.1) are unable to present a comprehensive and inclusive definition since it bears diverse connotation for different urban classes (George and Bearon, 1980). In other words, this concept has a special description about social welfare for any one in urban environment due to its diversity (Bond and Corner, 2004). In a general definition urban quality of life is having easy 
Table 1: Indexes of urban quality of life

\begin{tabular}{|c|c|}
\hline Source & Criteria and indexes \\
\hline Smith (2002) & $\begin{array}{l}\text { Life expectancy, } \% \text { of population in settlement with more than } 2000 \text {, protein consumption } \\
\text { per capita, curriculum in schools, curriculum in vocational centers, average people in room, } \\
\text { newspapers per } 1000 \text { person, No. of telephone per } 1000 \text { people, No. of radio users per } 1000 \text {, } \\
\text { active work force in agriculture, electricity consumption per capita (kw), steel consumption } \\
\text { per capita, (\%) of GNP from industry, foreign trade per capita, No. of salary employers and } \\
\text { wages earners (Smith, 2002). }\end{array}$ \\
\hline Schneider (1976) & $\begin{array}{l}\text { Income, wealth and employment, physical and mental health, education, crime and safety, } \\
\text { alienation and political participation (Schneider, 1976). }\end{array}$ \\
\hline Rabani-Khorasgani and Kianpour (2007) & $\begin{array}{l}\text { Satisfaction level from family life, job and income besides efficiency feeling, satisfaction } \\
\text { from government function, satisfaction from existed services(Rabani-Khorasgani and } \\
\text { Kianpour, 2007). }\end{array}$ \\
\hline Stohr and Velon, (1992) & $\begin{array}{l}\text { Amount of precipitation, percent of humidity, degree of temperature, wind speed, sun warmth, } \\
\text { ferrous crime, Proportion of teacher to student, rang of vision, participation, swage treatment, } \\
\text { waste disposal, places with high investment (Ibid). }\end{array}$ \\
\hline Population Crisis Committee (1990) & $\begin{array}{l}\text { Public and social security, food cost, living condition, housing standard, communication, } \\
\text { education, public health, peace and comfort, traffic, clean air (Population Crisis Committee, 1990). } \\
\text { Public safety, food cost, living condition, housing standard, communication, public health, } \\
\text { peace and education, traffic, clean air, , average of per capita income, purchase power }\end{array}$ \\
\hline UNDP (1995) & Life expectancy, literacy rate, average of per capita income \\
\hline Friedman (1997) & $\begin{array}{l}\text { Economic indexes (income, wealth, employment), environmental indexes (percent of } \\
\text { standard housing, air quality, family transport expenses), health indexes (infant mortality rate } \\
\text { per } 1000 \text { live birth, reported suicide rate), educational indexes (people under education in } \\
\text { schools and universities), indexes of participation and cooperation, social safety (drug abuse } \\
\text { and rubbery) (Friedman, 1997). }\end{array}$ \\
\hline Cardinal and Adin (2004) & $\begin{array}{l}\text { Cultural (percent of native (percent of people in religious ceremonies) Health (infant mortality } \\
\text { rate, percent of people with special disease) educational (rate of higher educated people. } \\
\text { No. of schools and higher education centers, No of students and staff), crime and safety } \\
\text { (No. of prisoners, No. of insurgences, rubbery and quarrelling and drug abuse), } \\
\text { employment (rate of employment) income (percent of people in under poverty line, } \\
\text { average income level) resources and environment (green space area, protected regions), } \\
\text { housing (durable houses, mean of people in room, none durable houses) air (quality, } \\
\text { level of dangerous gases) homelessness. }\end{array}$ \\
\hline Zivelova and Jansky (2008) & $\begin{array}{l}\text { Housing/economy and work (type of economic activities, unemployment, mean of income), } \\
\text { resources and environment (preserving the urban outskirt lands), city environment (rate of } \\
\text { traffic congestion, accessibility to services) health and health care, life expectancy, sudden } \\
\text { death) infant mortality rate, learning and skill, safe society (rate of crime, type of crime, fear } \\
\text { from crime incidence) (Zivelova and Jansky, 2008). }\end{array}$ \\
\hline
\end{tabular}

Table 2: Different indexes for Babolsar

\begin{tabular}{ll}
\hline Indexes & Sub-indexes \\
\hline Economic & (1) Income (2) Expenses (total expenses of household) \\
Social & (1) Education (2) Children safety \\
Physical and environmental & (1) Green space (2) Accessibility to green space (3) Accessibility to services \\
Mental and psychological & Satisfaction \\
\hline
\end{tabular}

access to comfort and basic needs (Eiser, 2004). In fact Quality of life could be translated into livability of a place; it means that in an urban society, quality of life relates to the common experiences of urban residents from urban environment and the ability of city to meet such needs. People perception about their environment may differ in different cultural backgrounds. A study in the Malaysian context revealed that local government has satisfied the citizen by taking environmental action in urban waste and sewage disposal (Zakaria et al., 2010). In fact quality of life in a city has its root in the efficiency of socio-economic, political deliberation (Myers, 1987). Generally, urban quality of life approach intends to create a healthy city and provide suitable urban services for all, in the framework of sustainability (Harpham et al, 2001). So in a healthy city with a high quality of life, physical and socioeconomic conditions are prepared to empower urban resident to flourish their capacities (Ashton, 1991). With respect to such circumstances, WHO defines quality of life as ideal condition for physical, mental and social satisfaction (Fayers and Machin, 2000). The concept of quality of life has transited accord with socio-economic and cultural change in time different time and space and so influenced by set of factors which consists the dynamic foundation of life in an urban environ (Fig. 1). Also, the concept of Ideal city which was characterized by clean air, sufficient public 
transport local small hospitals and accommodation for elderly and mental illness entered in the literature of urban studies in 1870 gained attention in the late decades of last century. Urban agencies were encouraged to utilize public co-operation in the form of civic, social and political participation. Urban quality of life and the related concepts (health city, eco-city, ideal city, utopia, sustainable city) has been considered by the Iranian scholars and has a significant stance in the academic discourse, but it was pursued more seriously from 1991 by the presentation of "healthy city" symposium and following the WHO catchphrase (slogan) on "healthy city for better life" in 1996, this triggered many urban project (56) to implement the principals of healthy city in the structure of urban development plans in the country (Lotfi and Solaimani, 2009). The present study aims to investigate the level of quality of life in the city of Babolsar in the southern coast of the Caspian Sea in Mazandaran province. The research intends to study socio-economic and physical condition of city contributed to the urban quality of life.

Criteria and Indicators of urban quality of life: The subject of urban quality of life and the promotion of its concept in particular, has always been the central focus of urban planners. This term is a multi-conceptual and dimensions. However most of the scholars have agreed that the concept consisted from two main dimensions; objective and subjective which these two approaches are used for its measuring. The first one investigates objective indicators such as housing and socioeconomic characteristics while the second studies subjective indictors like the level of satisfaction and motivation. To understand and introduce the quality of life in a city both indicators should taken in account as they complete each other (Angur and Widgery, 2004), some believe that city is a multi-aspects phenomena and so the quality of life must be measured in respect to the all different dimensions.

Schalock (2004) by conducting a depth study using many exact criteria introduced eight indexes which are: (1) psychological satisfaction (lack of stress, dignity), (2) inter-personal relations (mutual interaction, support and communication) (3) material security (employment, housing), (4) personal growth (education, personal eligibility and function), (5) physical happiness ( health, daily physical activity, recreation) (6) right to determine self-destiny (personal independency, goals, values and priorities), (7) social participation (social role and supports) and (8) rights (human rights, citizenship). This study has determined indexes and sub-indexes with respect to the Iranian socio-economic background and the availability of data (Table 2).

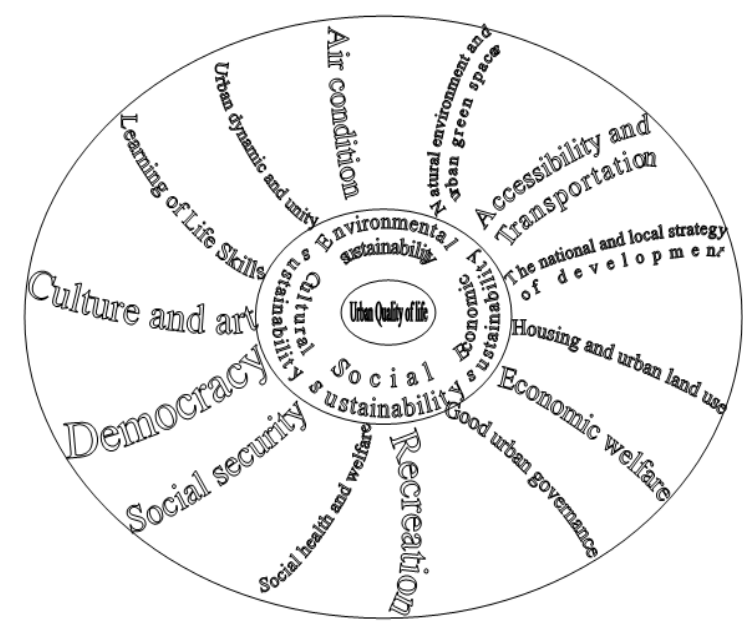

Fig. 1: Conceptual framework of urban quality of life

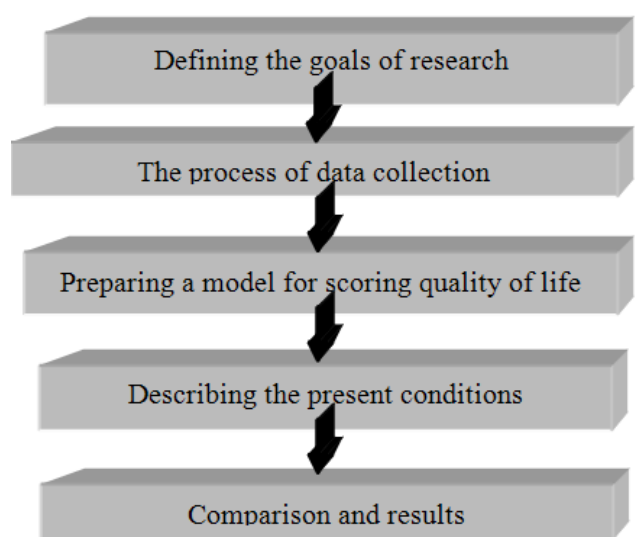

Fig. 2: The process of the research

\section{MATERIALS AND METHODS}

The methodology is based on a descriptiveanalytical method which was associated with conducting a field work to complete questionnaires (Fig. 2). The research selected 400 samples via Cocaran formula with a certainty degree of 95.5. Questionnaires were distributed in three large areas as central, western and eastern parts of the city for 16 neighborhoods. Also Delphi method was applied to select the different indexes to increase the clarity of the questionnaires with respect to physical and socio-economic quality:

$$
\mathrm{N}=\frac{\frac{\mathrm{t}^{2} \mathrm{pq}}{\mathrm{d}^{2}}}{1+\frac{1}{\mathrm{~N}}\left(\frac{\mathrm{t}^{2} \mathrm{pq}}{\mathrm{d}^{2}}-1\right)} \mathrm{T}=2, \mathrm{~N}=50032, \mathrm{P}=0 / 5, \mathrm{q}=0 / 5
$$


Table 3: Ranking the level of quality of life

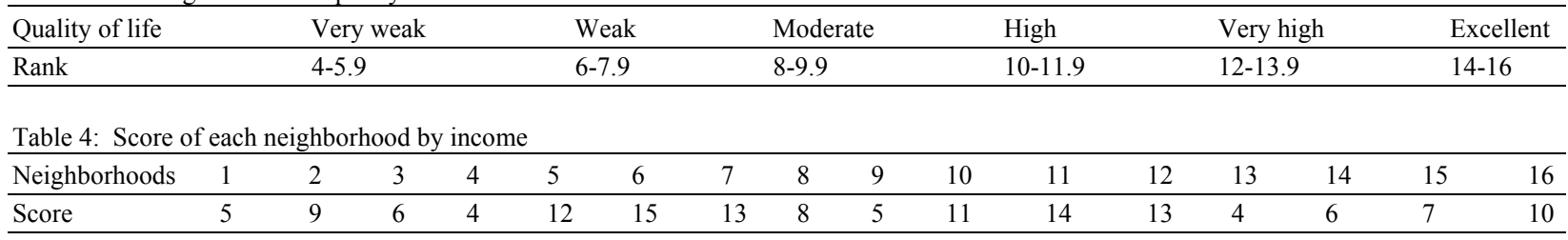

Table 5: Score of neighborhoods by cost mean

\begin{tabular}{|c|c|c|c|c|c|c|c|c|c|c|c|c|c|c|c|c|}
\hline Neighborhoods & 1 & 2 & 3 & 4 & 5 & 6 & 7 & 8 & 9 & 10 & 11 & 12 & 13 & 14 & 15 & 16 \\
\hline Score & 6 & 8 & 16 & 6 & 9 & 10 & 12 & 8 & 7 & 14 & 15 & 13 & 6 & 7 & 8 & 11 \\
\hline
\end{tabular}

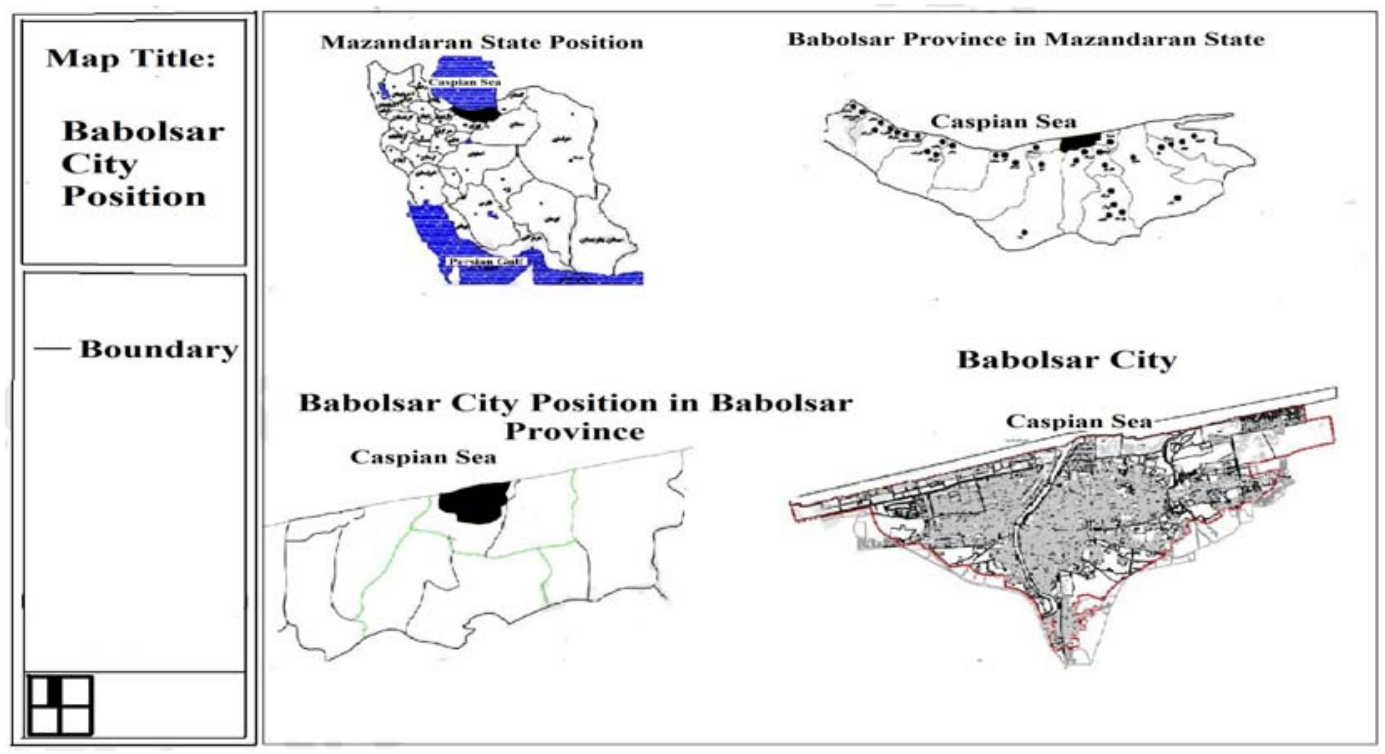

Fig. 3: Geographical location of Babolsar in Iran and Mazandaran

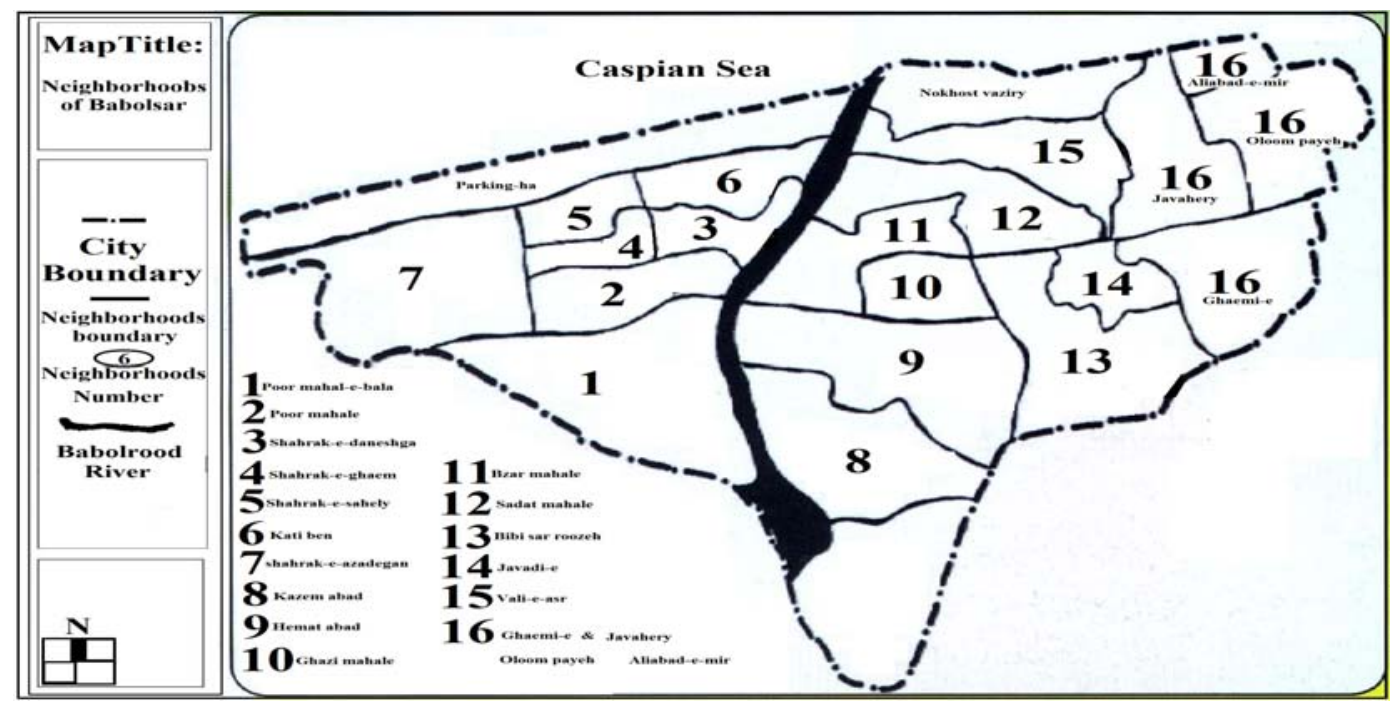

Fig. 4: Neighborhoods of Babolsar 
There has been an attempt to select indexes which had potential to match with local condition, since there is not global standard index.

Calculating score of quality of life: To measure the quality of the total scores of each factor was divided to the sum of factors in each neighborhood to obtain the mean of quality of life. Then all of the neighborhoods means were summed up and divided to the numbers of neighborhoods, so that the mean of quality of life was determined for the city (Table 3 ).

The city and its setting: Babolsar has an area of 1350 ha in the alluvial fan of Babolrood River in the southern part of the Caspian Sea in Mazandaran Province (Fig. 3). The city is located in the $249 \mathrm{~km}$ distance from the capital Tehran and $62 \mathrm{~km}$ from the provincial center Sari. Babolsar had a population of 50032 in 2006 which compared to the last decade had a growth of $1.23 \%$. The city is divided into 16 neighborhoods (Fig. 4). The age composition shows that $48 \%$ of the town population is less than 15 years old and 18\% consists from 16-64 age groups.

The main function of the city is tourism and also the city has a fertile agricultural hinterland which produces rice and citrus fruit. Furthermore the only state owned university is located here.

\section{RESULTS}

The given indexes were divided into four general groups in this research which are: (a) economic, (b) social, (c) physical environmental and (d) mental or subjective.
Economic indexes: Two indexes of income and living cost have considered as economic indexes.

Income: Income is one of the important factors which have a key role to show the social standing and position. Since this index could not be obtained in the Iranian cities exactly, so emphasis on this index is not reasonable. The sampling results showed that the mean of income for the city's household was 5200000 Rials (10000R=1\$US). The minimum and maximum income has been 1000000 and 30000000 Rials respectively. The highest income level was belonged to neighborhoods 3 and the lowest level recorded from neighborhoods 4 and 13 (Fig. 5, Table 4).

Cost: Living costs of households is an important index which indicates the subsistence conditions of urban population. Despite the fact that people are reluctant to state the exact amount their earnings but they usually announce their expenditures due to cultural and sychological backgrounds.

Table 6: No and \% of Literacy in Babolsar (sampled)

\begin{tabular}{lrrrrr}
\hline \multicolumn{5}{c}{ Literate } & \multicolumn{4}{c}{ Illiterate } \\
\cline { 2 - 6 } Literacy & \multicolumn{1}{c}{ No } & \multicolumn{1}{c}{ (\%) } & No & (\%) & Total \\
\hline 1 & 86 & 77.8 & 12 & 12.2 & 98 \\
2 & 231 & 92.4 & 19 & 7.6 & 250 \\
3 & 53 & 100.0 & - & - & 53 \\
4 & 90 & 92.8 & 7 & 7.2 & 97 \\
5 & 135 & 97.7 & 3 & 2.3 & 128 \\
6 & 58 & 90.6 & 6 & 9.4 & 64 \\
7 & 65 & 87.8 & 9 & 12.2 & 74 \\
8 & 131 & 100.0 & - & - & 131 \\
9 & 262 & 90.3 & 28 & 9.7 & 290 \\
10 & 136 & 95.1 & 7 & 4.9 & 143 \\
11 & 177 & 91.7 & 16 & 8.3 & 193 \\
12 & 194 & 91.9 & 17 & 8.1 & 211 \\
13 & 135 & 73.0 & 50 & 27.0 & 185 \\
14 & 94 & 88.7 & 12 & 11.3 & 106 \\
15 & 82 & 88.2 & 11 & 11.8 & 93 \\
16 & 90 & 90.0 & 10 & 10.0 & 100 \\
\hline
\end{tabular}

Table 7: Scores of neighborhoods by literacy

\begin{tabular}{|c|c|c|c|c|c|c|c|c|c|c|c|c|c|c|c|c|}
\hline Neighborhoods & 1 & 2 & 3 & 4 & 5 & 6 & 7 & 8 & 9 & 10 & 11 & 12 & 13 & 14 & 15 & 16 \\
\hline Score & 4 & 13 & 16 & 14 & 15 & 10 & 5 & 16 & 9 & 15 & 11 & 12 & 3 & 7 & 6 & 8 \\
\hline
\end{tabular}

Table 8: People in different curriculum (\%)

Curriculum

\begin{tabular}{|c|c|c|c|c|c|c|c|c|c|}
\hline \multicolumn{2}{|c|}{ Primary } & \multicolumn{2}{|c|}{ Secondary } & \multicolumn{2}{|c|}{ High school } & \multicolumn{2}{|c|}{ Higher } & \multirow[b]{2}{*}{ Mean } & \multirow[b]{2}{*}{ Total } \\
\hline No & $(\%)$ & No & $(\%)$ & No & $(\%)$ & No & $(\%)$ & & \\
\hline 419 & 20.7 & 275 & 13.6 & 1010 & 49.9 & 321 & 15.8 & 9.6 & 2025 \\
\hline
\end{tabular}

Table 9: Neighborhoods score by \% of children safety

\begin{tabular}{lllllllllllllllll}
\hline Neighborhoods & 1 & 2 & 3 & 4 & 5 & 6 & 7 & 8 & 9 & 10 & 11 & 12 & 13 & 14 & 15 & 16 \\
\hline Score & 5 & 9 & 14 & 15 & 9 & 13 & 12 & 6 & 10 & 11 & 10 & 16 & 7 & 15 & 12 & 8
\end{tabular}


This study showed that neighborhoods 3 and 13 had the highest level of household living cost and neighborhoods 1, 4 and 13 had the lowest one (Table 5 and Fig. 6). The main reason behind such contrast is that the first areas are inhabited by the high income families who have access to better welfare.

Social indexes: To study the social indexes two criteria of education and children safety are considered. Literacy is one of the main indicators which could indicate the social stance of people in developing countries as still some urban residents are illiterate. The research showed about $90.9 \%$ of the city's population was literate and the rest remained illiterate. Also the details revealed that neighborhoods 3 and 8 were among the highest educated areas and neighborhood 13 gained the lowest level (Table 6 and 7). To rank the different neighborhoods the percent of literacy was used for scoring.

The distribution of curriculum among the city's educated people indicated new information. According to this statistic, $20.7 \%$ of the people educated in primary, $13.6 \%$ passed secondary stage, $49.9 \%$ have been educated from high school and finally $15.8 \%$ were higher educated (Table 8).

Children safety; In general the index of social safety is very important criteria in analyzing urban quality of life by considering the children safety and the feeling of parents about the security of the community. Such criterion has close relation to other factors (level of education, history of community, level of economic welfare). According to the present study the central neighborhoods had higher level of satisfaction compared to the margin neighborhoods.

Aliabadmir reported a high level of satisfaction despite its remoteness to the central part of the city. Such condition is due to the fact this area favors a private environment and the commute of people is controlled by gate keepers (Table 9 and Fig. 7).

Physical and environmental indexes: The physical and environmental indexes include accessibility to the urban green space and natural ecosystems. The study revealed that accessibility to parks has been very high in 5 neighborhoods which include Nokhostvaziri, Valiasr, Sadatmohalleh, Katibon, Sharak Daneshgah. The least accessibility was recorded from peripheral neighborhoods. The main reason of such low accessibility was related to the lack of green space in these areas.

Urban green spaces: Urban green space is one of the important land uses which could illustrate one aspect of

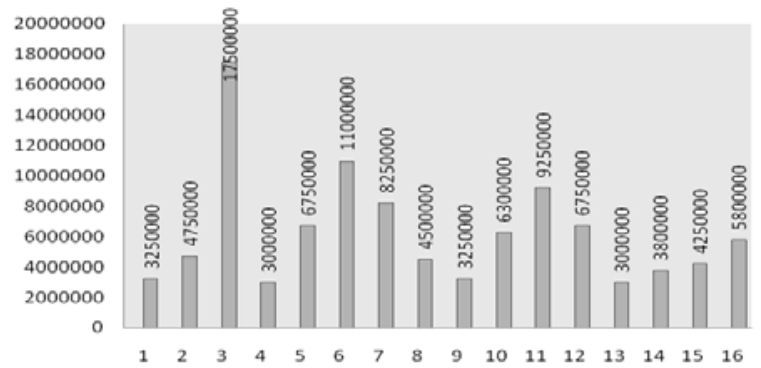

Fig. 5: Mean of income (Rial) in different neighborhoods

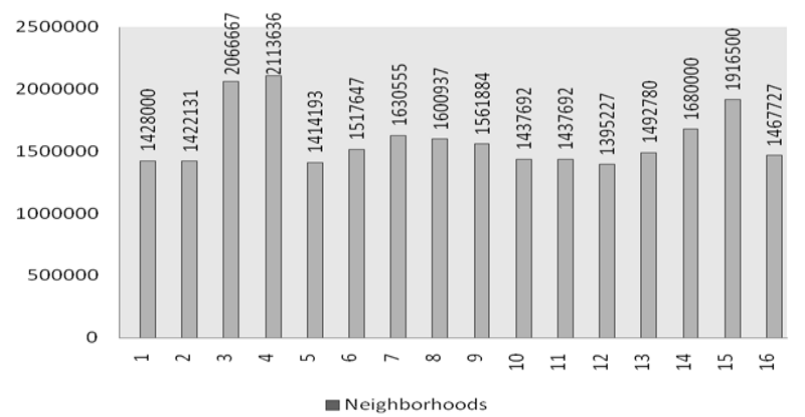

Fig. 6: The mean of household costs (Rial)

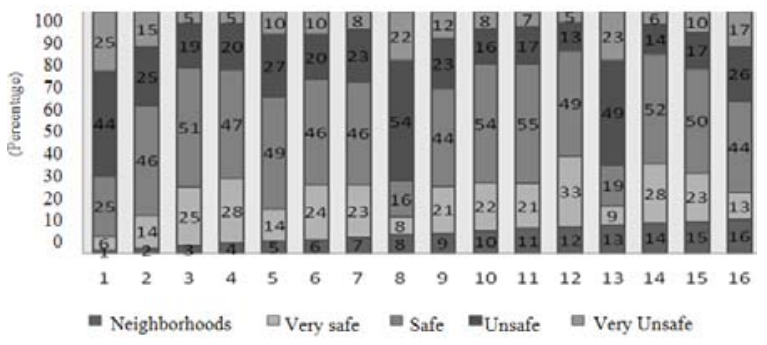

Fig. 7: Children safety in neighborhoods

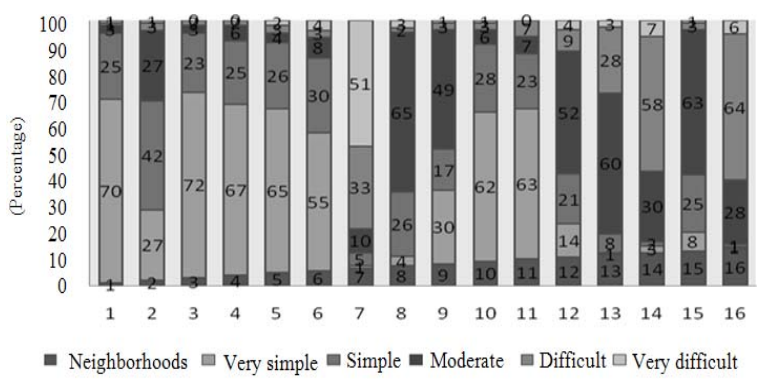

Fig. 8: Accessibility of neighborhoods to parks

Table 10: Area and park ratio in Babolsar

\begin{tabular}{llll}
\hline Scale of park & No. of parks & Area $\mathrm{m}^{2}$ & Ratio per person $\mathrm{m}^{2}$ \\
\hline Neighborhood & 7 & 21000 & 0.32 \\
Local & 1 & 11100 & 0.16 \\
Region & 1 & 36000 & 0.53 \\
Zone & - & - & - \\
Total & 9 & 68100 & 1.01 \\
\hline
\end{tabular}


quality of life as it functions in two major ways. First green space has environment effect on the microclimate of the cities and second it provides opportunities for residents to spend their spare times in parks and natural landscapes. The extend and location of green space are assigned by master and detailed plans in the Iranian urban centers. The total area of green space has been about 13.8 ha in Babolsar which per person ratio is about $3.06 \mathrm{~m}^{2}$. This amount includes all of types of green space from street islands to local parks. The suggested ratio for each person is 7 $\mathrm{m}^{2}$ by the new detail plan of the city. The research revealed that there are nine parks in city with an area of $68100 \mathrm{~m}^{2}$ which the ratio would be $1.01 \mathrm{~m}^{2}$ for each resident. The distribution of parks shows that 7 of the function in the neighborhood level, one in local scale and the other has a regional function.

According to the standards of the Iranian urban development plans, the acceptable ration of green space should be from $7-12 \mathrm{~m}^{2}$ in cities, however this index is lesser that the amount of UN environment department as it is $30 \mathrm{~m}^{2}$ for each city resident. There for the city suffer from the shortage of parks in all spatial scales (Table 11).

Access to park and green space: Accessibility to different services is a key index to indicate an aspect of urban quality of life. Access to urban green space was questioned in this study. The results showed that the neighborhoods of 1, 4.5 and 11 had higher accessibility to parks while neighborhoods of 7,13 and 16 obtained lower scores in this research (Table 10 and 12, Fig. 8).

Access to services: Success of cities towards sustainability is depended to the methods of transportation and accessibility. So provision of public services could have great influence on urban quality of life (Cohail, 2008). The study indicated that the central neighborhoods had a better accessibility to the urban services (medical, educational and transport) compared to the peripheral areas (Table 13 and Fig. 9).

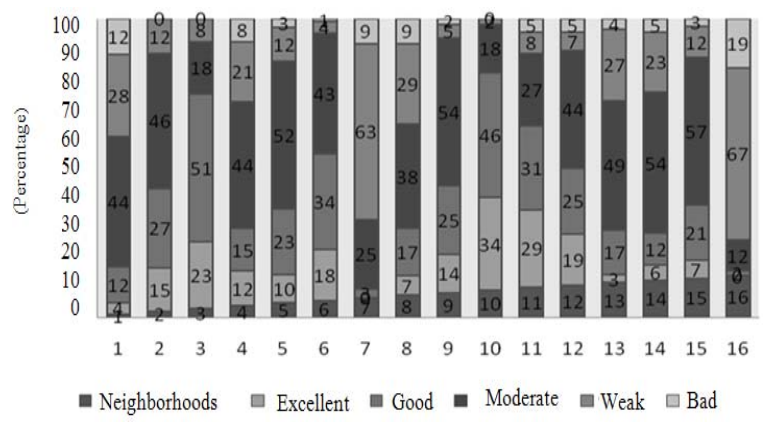

Fig. 9: Accessibility of neighborhoods to urban services

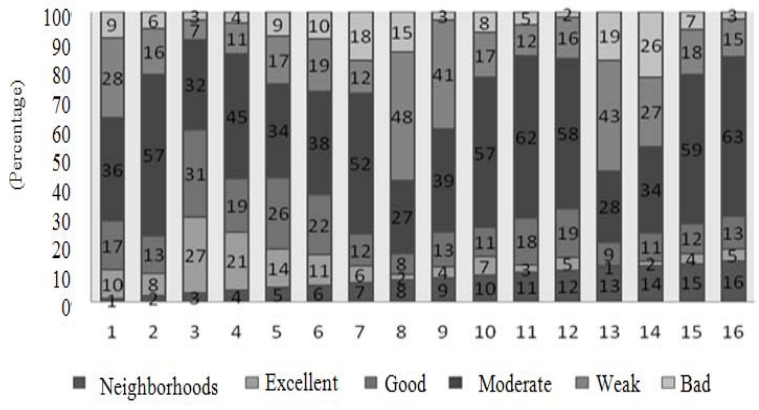

Fig. 10: The level of satisfaction on the base of personal, family and employment

Table 11: Existed ration per person and the standard ratio by parks

\begin{tabular}{lll}
\hline Scale of park & Existed ratio per person $\mathrm{m}^{2}$ & Standard $\mathrm{m}^{2}$ \\
\hline Neighborhood & 0.40 & 1.2 \\
Local & 0.30 & 1.5 \\
Region & 0.53 & 1.8 \\
Zone & - & 4.5 \\
Total & 1.22 & 9.0 \\
\hline
\end{tabular}

Table 12: Neighborhoods score by accessibility to Park

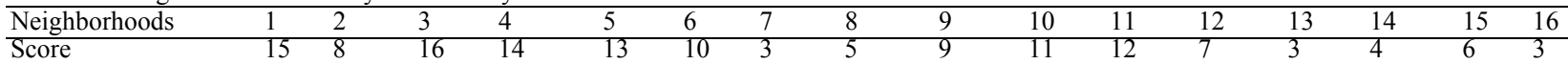

Table 13: Neighborhoods score by $\%$ of accessibility to services

\begin{tabular}{|c|c|c|c|c|c|c|c|c|c|c|c|c|c|c|c|c|}
\hline oods & 1 & 2 & 3 & 4 & 5 & 6 & 7 & 8 & 9 & 10 & 11 & 12 & 13 & 14 & 15 & 16 \\
\hline Score & 5 & 11 & 14 & 9 & 8 & 12 & 3 & 7 & 10 & 16 & 15 & 13 & 4 & 6 & 7 & \\
\hline
\end{tabular}

Table 14: Neighborhoods score by \% of satisfaction

\begin{tabular}{llllllllllllllllll}
\hline Neighborhoods & 1 & 2 & 3 & 4 & 5 & 6 & 7 & 8 & 9 & 10 & 11 & 12 & 13 & 14 & 15 & 16 \\
\hline Score & 12 & 11 & 16 & 15 & 14 & 13 & 9 & 5 & 7 & 10 & 6 & 8 & 4 & 5 & 7 & 8
\end{tabular}

Table 15: Neighborhoods scores by all indexes

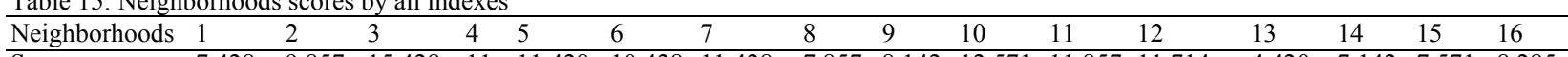

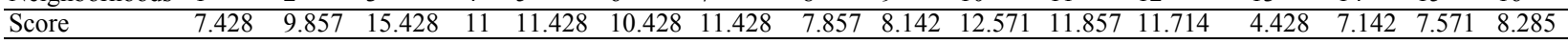

Table 16: Urban quality of life in Babolsar

\begin{tabular}{lllllll}
\hline Quality of life & Very weak & Weak & Moderate & High & Very high & Excellent \\
\hline Neighborhoods & 13 & $1,8,15,14,16$ & $2,7,8$ & $4,5,6,11,17$ & 10 & 3 \\
\hline
\end{tabular}




\section{DISCUSSION}

There are variations among the selected indexes contributed to the quality of life in researches, but almost all of them tried to present an approach which present the attitude of urban residents about their life. As objective indexes may indicate similar situations in some parts of cities but subjective indicators represent different picture of people aspirations and wants. So measuring mental attitudes of people about their living could complement the physical indexes of urban areas. This study questioned and measured feeling of happiness in three aspects of employment, family and personal. Figures show the variation of the satisfaction among different neighborhoods (Fig. 10). Ranking of neighborhoods was done with respect to the quality indexes of Table 14, which the most deprived area is neighborhood 13 (Bibi Sarroozeh). In fact there is a spatial break between western and eastern areas of the city especially between 13-15 1nd 16 with neighborhoods of 2-7.

Also the total scores of the neighborhoods are 8.517 which mean the city has a moderate level of quality of life. There has been a meaningful relation between level of satisfaction and economic condition. In other words the neighborhoods with higher level of economic indexes were more satisfied compared to the lower ones. It also could be discussed that in the Iranian context, urban quality of life is highly depended to the citizen perception about the meaning of happiness. However the present research has proved a positive correlation between physical accessibility and satisfaction but it seems that further research could unveil the deeper layers of the general perception and attitudes of the small and intermediate urban places in the north of Iran.

\section{CONCLUSION}

The main aim of this research was measure urban quality of life in Babolsar by using weighting model. Generally man tries to promote his life quality to reach better condition of welfare and comfort for development, so such struggles is a dynamic phenomenon which changes all of times in human settlement. Babolsar as touristic city is highly depended to its natural asset i.e. the sea. Here like other parts of the world (Theodoropoulou et al., 2009) urban week infrastructures has created neighborhoods with low quality of life and an internal movement of people . Researchers showed that the level of quality of life could be gauged in two aspects via objective and subjective factors and so in different environment or in the different neighborhoods of a city (Lotfi and Koohsari, 2009). As it was noted there is no single standard for all cities worldwide to measure the quality of life due to the diversity of cultural, socio-economic and physical conditions. This study attempted to define and apply models which had more correspondence with the Iranian context. We have used comparative weighting method to investigate quality of life in Babolsar. The results revealed variation among the 16 neighborhoods of the city on the base of total scores in Table 15 and 16.

So the priority of planning should concentrate on the areas where deprivation decreased the level of quality of life. The neighborhoods of 13, 16, 15, 14, 1 and 8 are the most areas which need planning measures by local authorities.

\section{REFERENCES}

Angur, M.G. and R. Widgery, 2004. Congruence among objective and subjective Quality-of-Life (QOL) indicators. Alliance J. Bus. Res. http://ajbr.org/index.htm

Ashton, J., 1991. The healthy cities project: A challenge for health education. Health Edu. Behav. 18: 39-48. DOI: $10.1177 / 109019819101800105$

Bond, J. and L. Corner, 2004. Quality of Life and Older People. 1st Edn.,Open University Press, London, ISBN-10: 033520872X, pp: 152.

Cardinal, N. and K. Adin, 2004. An urban aboriginal life, the 2005 indicator on quality of life of aboriginal people in the greater vancouver area. Center Native Policy Res., http://www.cnpr.ca/OnlinePublications.aspx

Eiser, C., 2004. Children with Cancer: The Quality of Life. 1st Edn., Lawrence Erlbaum Associates, Publishers, London, ISBN-10: 080583544X, pp: 344.

Fahy, F., 2007. Galway 21: Implementing the Principles and Practices of Sustainable Development in Galway City Council. $1^{\text {st }}$ Edn., Environmental Protection Agency, USA., ISBN10: 1840951214, pp: 37.

Fayers, M.M. and D. Machin, 2000. Quality of Life: Assessment, Analysis and Interpretation. 1st Edn., University of Sheffield, John Wiley and Sons Ltd Press, UK. ISBN-10: 0471968617, pp: 404.

Friedman, M.I., 1997. Improving the Quality of Life: A Holistic Scientific Strategy. 1st Edn., Praeger, London, ISBN-10: 0275960285, pp: 208.

George, L.K. and L.B. Bearon, 1980. Quality of Life in Older Persons: Meaning and Measurement. 1st Edn., Human Sciences Press, New York, 0877054886, pp: 238. 
Harpham, T., S. Burton and I. Blue, 2001. Healthy city projects in developing countries: The first evaluation. Health Promot. Int., 16: 111-125. PMID: 11356750

Lotfi, S. and K. Solaimani, 2009. An assessment of urban quality of life by using analytic hierarchy process approach (case study: Comparative study of quality of life in the North of Iran). J. Soc. Sci., 5: 123-133. DOI:10.3844/jssp.2009.123.133

Lotfi, S. and M.J. Koohsari, 2009. Analyzing accessibility dimension of urban quality of life: Where urban designers face duality between subjective and objective reading of place. Soc. Indic. Res., 49: 417-435. DOI: 10.1007/s11205009-9438-5

Morris, A., 1998. Geography and Development. 1st Edn., Routledge, UK., ISBN-10: 1857280814, pp: 256.

Myers, D., 1987. Community-relevant measurement of quality of life a focus on local trends, University of texas at Austin. Urban Affalrs Q., 23: 108-125.

Naghdi, A. and R. Sadeghi, 2006. Shonty town, a challenge for sustainable development (a case suty of Hamadan city, Iran). Q. J. Soc. Walfare, 20: 213-233.

Population Crisis Committee, 1990. Cities: Life in the world's 100 largest metropolitan areas. Washington DC: Population Crisis Committee.
Rabani-Khorasgani, A. and M. Kianpoor, 2007. Presenting a model for Isfahan quality of life. J. Liter. Hum. Sci., 58: 67-107.

Schalock, R.T., 2004. The concept of quality of life: What we know and do not know. J. Int. Disability Res., 48: 203-216.

Schneider, M., 1976. The quality of life and social indicators research. Public Admin. Rev., 36: 297-305.

Smith, D., 2002. Quality of life. Human welfare and social justice, translated into Persian by: Hataminejad, H. and Haekmat-shahi Ardebili. J. Polit Econ., 6: 160-173.

Theodoropoulou, H., R. Mitoula and M. Vamvakari, 2009. Sustainable regional development. J. Soc. Sci., 5: 80-84. ISSN: 1549-3652

UNDP., 1995. Improving rural shelter in developing countries. 1st Edn., United Nations Centre for Human Settlements, ISBN-10: 9211312973, pp: 46.

Zakaria, Z., N. Noordin and M.Z.H.M. Sawal, 2010. Environmental functions provided by Malaysian local government: User's perception. J. Soc. Sci., 6: 296-302. ISSN: 1549-3652

Zivelova, I. and J. Jansky, 2008. Analysis of life quality development in the administrative districts of South Moravia. Agric. Econ. Czech, 54: 431-439. 